\title{
Innovative cyclical development of the Russian pipeline system
}

\author{
V. Kurushina \& Y. Zemenkov \\ Tyumen State Oil and Gas University, Russia
}

\begin{abstract}
This paper examines the identification of patterns of innovative development in the Russian pipeline system. An evaluation system based on the theory of technological innovation cycles is proposed. The innovation cycles identification scheme, in terms of innovation objects, is designed; the innovation dynamics are analyzed on the basis of chronological maps and a comparative evaluation of the waves of innovations in oil transportation is conducted. The influence of industrial specificity of groups of elements on the rate of innovative change is revealed. A forecast of pipeline system elements' innovative renewal is produced using Foresight assessments of priority technologies 2030.
\end{abstract}

Keywords: pipeline system, technological innovation cycle, objects of innovation, speed of innovation changes.

\section{Introduction}

Pipeline transportation of hydrocarbons performs an essential function within the energy security system - key energy sources' transfer from mining areas to consumption areas. Thereby innovative updating process of oil and gas pipeline systems is always the focus of attention of scientists and engineers. However, modern researches of process of scientific and technological development of trunk lines either provide an overview of development activities or a chronological description of the introduction of new technologies, or analysis of individual innovation. This paper represents an attempt to carry out systematic analysis of innovative development of Russian oil transportation system since 1878 on the basis of an evolutionary approach. The purpose of research is identification patterns of development from the perspective of the modern theory of technological innovation cycles. 


\section{Evaluation of innovative development}

Innovative development is carried out non-linearly. Many researchers such as J. Schumpeter (1934), R. Stoubaugh (1988), R. Henderson and K. Clark (1990), R. Moriarty and T. Kosnik (1990), S. Freeman (1994), M. Lee and D. Na (1994), K. Atuahene-Gima (1995), R. Balachandra and J. Friar (1997), E. Kessler and A. Chakrabarti (1999) allocate incremental and radical innovations. V. Medynsky (2002) and S. Ildemenov (2003) use the terms ordinary and radical, M. Coccia (2005) - elementary (micro-incremental) and cluster (new technological system). Spasmodic character of development is described by the unified theory of innovation cycles [1] and the theory of technological structures (ways) of Glazyev [2] representing the innovative development as a generational change of techniques and technologies. A cycle of technological innovation is understood as a set of technologies that exist in a certain area in a certain period of time, as well as the period of technologies' domination itself. Innovations are linked into a single multi-technical system within which they support the use and development of each other in technological innovation cycle. In the growth phase of technological innovation cycle there is a transformation of production processes on the basis of main (basic, core) innovations (a key factor of the cycle) that are fundamentally different from the previous generation of technologies. Technologically associated productions based on the main innovations develop the most rapidly over the cycle. They are called the core of the cycle. The advantages of the theory of technological ways are: 1) systematicity; 2) objectivity which is manifested in the adequacy of technological cycle times to Kondratieff long waves (K-Waves); 3) the applicability to the technical systems; 4) the presence of criteria to identify the cycle; 5) the ability to forecast innovative development based on the structure of a new cycle.

The object of this study is oil pipeline system of Russia. The study period is from 1878 to 2010. Subject of research is innovation patterns. Methodological framework is the theory of technological structures of S. Glazyev. The source base is provided by extensive materials from periodicals and literature on innovations in the main and field pipelines in Russia: scientific publications of R. N. Bakhtizin, T. V. Dmitrieva, V. P. Karpov, B. N. Mastobaev, E. M. Movsumzade, A. Y. Khavkin, A. M. Shammazov [3-8].

\subsection{Method of estimation}

Detailing the object of the study was carried out in two ways: 1) by components of the technological mode of production (i) - the materials, techniques and technologies, 2) by processes (j). Highlighted items allowed submitting pipeline transport system as a set $(\mathrm{A})$ of objects of innovation $\left(\mathrm{X}_{\mathrm{ij}}\right)$ : 


$$
A=\left(\begin{array}{cccc}
X_{11} & X_{12} & \ldots & X_{1 j} \\
X_{21} & X_{22} & \ldots & X_{2 j} \\
\ldots & \ldots & \ldots & \ldots \\
X_{i 1} & X_{i 2} & \ldots & X_{i j}
\end{array}\right)
$$

Sixteen elements called markers of innovations in the author's terminology were identified from the above set of $\mathrm{X}_{\mathrm{ij}}$. Selection is made on the basis of the following criteria:

- importance in performing the functions of the technical system;

- availability of information base on the objects of innovation;

- $\quad$ the level and the dynamics of innovation development of the element.

The innovation data array during the analyzed period was established in terms of markers of innovation. An important stage of the study was the cycles' identification procedure of innovations. S. Glazyev allocates 6 structures, and each structure corresponds to a certain key factor and a set of related industries (a core). For example, pipeline transport was created during the period of the 2 nd technological way. The key factor of this way is the steam drive, and the core includes railway construction, metallurgy, engineering, steamship construction, coal and machine-tool industry. The identification with assigning numbers of technological ways $\mathrm{N}_{\mathrm{ijt}}$ was carried out for each marker $\mathrm{X}_{\mathrm{ijt}}$ at a particular time (Figure 1).

Chronological maps were constructed in accordance with 16 markers of innovations in the coordinates of "time" - "number of technological way" using the revealed results. Study on the chronological map allows to visualize the paths of development in the dynamics, and to analyze the implementation of core innovations for each element of the system on a 6-point scale. Figure 2 shows the example of chronological map of innovation of energy drive equipment.

Steam drive corresponding the $2^{\text {nd }}$ technological way was used since the formation of Russian oil transportation system. Steam engines were used during the construction of the first main kerosene pipeline in Russia (1896-1905) along with diesel engines complying the $4^{\text {th }}$ technological way. In the $50 \mathrm{~s}$ of the $20^{\text {th }}$ century there was a change of steam and diesel engines for electric motors (the $3^{\text {rd }}$ technological way). Since the 70 s gas turbine units (GTU) corresponding to the $4^{\text {th }}$ technological way were commissioned. Study of chronological maps suggests that the evolution of energy-producing equipment is nonlinear with the simultaneous development on several fronts.

\subsection{Comparative evaluation of innovative development}

Identification of system elements' states to a technological way allows not only to investigate the dynamics in chronological map but also to determine the level of innovative development of a selected set of elements at any given time. For example, it was found that in 2010 the average level of innovative development in Russian pipeline system on materials was -4.6 , on technique -4.0 , on technology -3.7 (on a scale of technological structures). On the process of 
884 Energy Production and Management in the 21st Century, Vol. 2

pipelines construction -3.9 , on the oil pumping -4.1 , on the diagnostics -4.5 , on the oil storage - 4.0. In general, the level of development of the industry is 4.1 (table 1). Technologies used today in the construction and operation of pipeline systems in Russia correspond to the growth of the $5^{\text {th }}$ technological cycle and the infancy of the $6^{\text {th }}$ cycle.

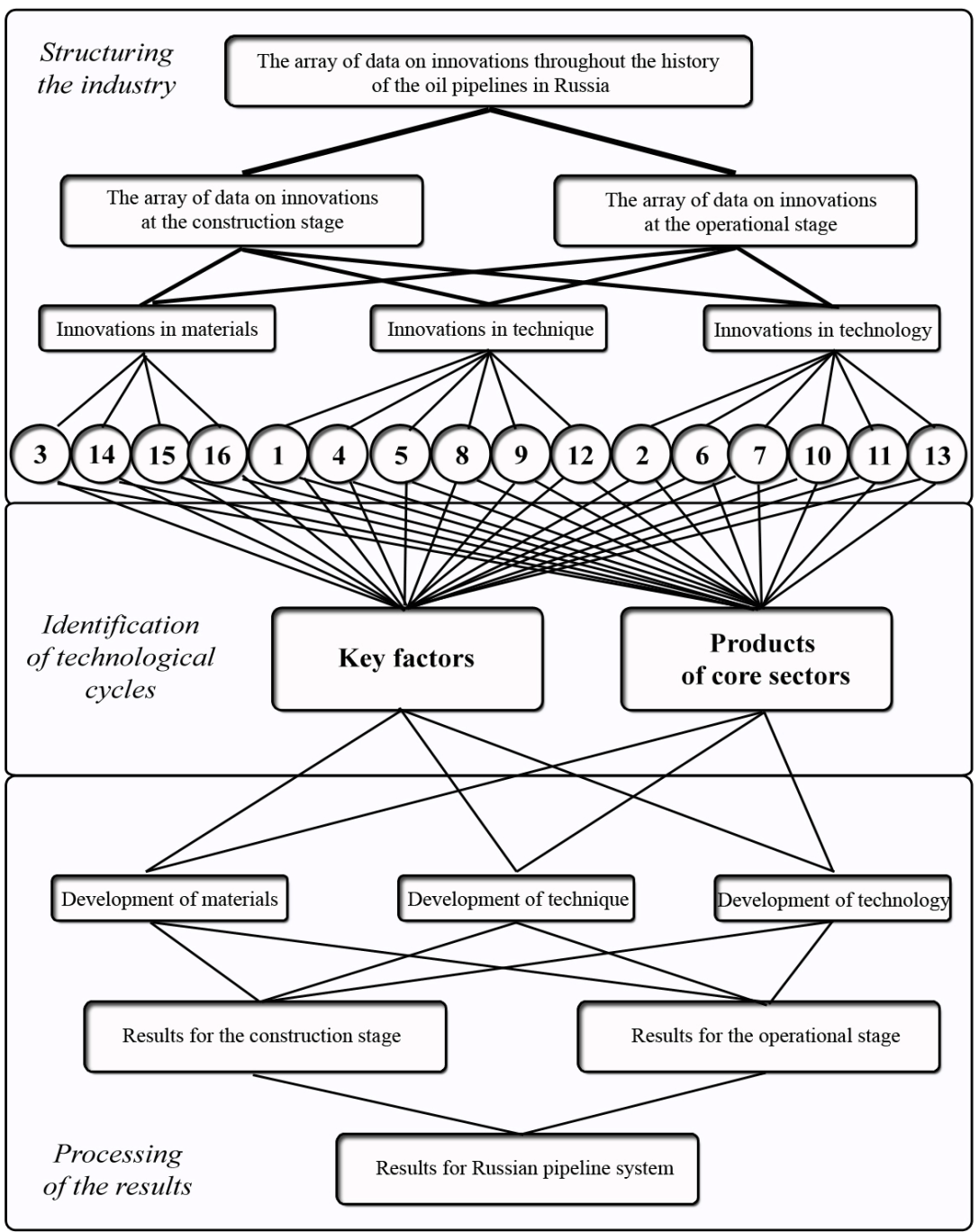

Figure 1: $\quad$ Technological cycles' identification scheme. 


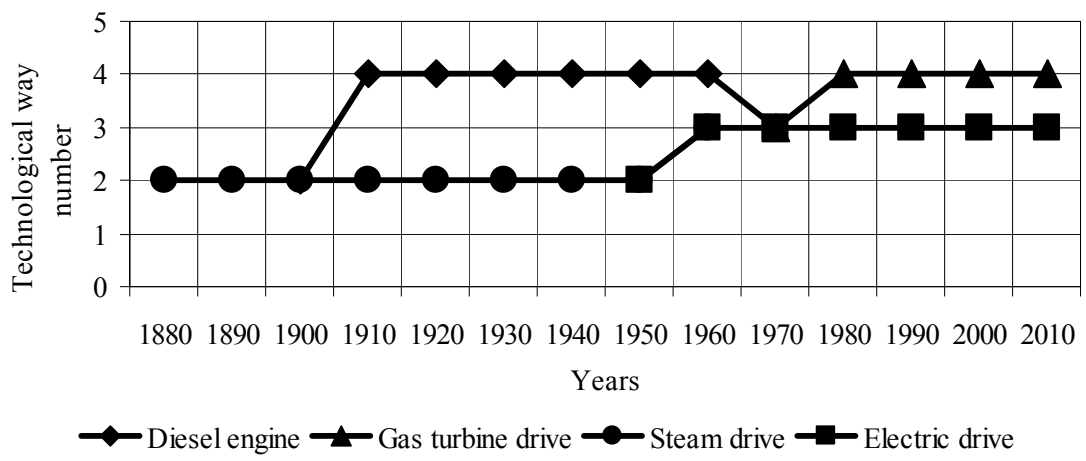

Figure 2: $\quad$ Chronological map of innovations of energy drive equipment.

Table 1: Comparative evaluation of innovative development of pipeline transport (on a scale of technological ways).

\begin{tabular}{|l|c|c|}
\hline & $\begin{array}{c}\text { Average value } \\
\text { of TW }\end{array}$ & $\begin{array}{c}\text { Technological } \\
\text { delay, years }\end{array}$ \\
\hline Russian pipeline system & 4.1 & 12 \\
\hline Russia* & 3.8 & 24 \\
\hline USA $^{*}$ & 4.4 & standard \\
\hline
\end{tabular}

* Calculated on the basis of the data of the writers [9].

According to the estimates, the average level of innovative development of pipeline transport is higher than in Russia as a whole but lower than in the USA. Furthermore, not only innovation cycles were highlighted in the pipeline system, but also the start and end dates of the waves of techniques and technologies' generational change were clarified (table 2). Terms of becoming the $5^{\text {th }}$ technological structure were predicted by the current trend of reducing the technological gap.

Table 2: Comparative evaluation of the formation of technological ways in the Russian pipeline system.

\begin{tabular}{|c|c|c|c|}
\hline \multirow{2}{*}{ \# TW } & Authors' estimate & \multicolumn{2}{|c|}{ S. Glazyev's estimate } \\
\cline { 2 - 4 } & Russian pipelines & $\begin{array}{c}\text { World processing } \\
\text { facility }\end{array}$ & Key factor of the cycle \\
\hline 1 & - & $1770-1830$ & Textile machines \\
\hline 2 & $1878-1950$ & $1830-1880$ & Steam drive \\
\hline 3 & $1950-1970$ & $1880-1930$ & Electric motor \\
\hline 4 & $1970-1990$ & $1930-1970$ & $\begin{array}{c}\text { Internal combustion } \\
\text { engine }\end{array}$ \\
\hline 5 & $1990-2025$ & $1970-2010$ & $\begin{array}{c}\text { Microelectronic } \\
\text { components }\end{array}$ \\
\hline
\end{tabular}


A study of development using the chronological maps revealed different rates of innovation update of pipeline system elements. Grouping the objects of innovations on the speed of technological renovation was performed to identify these patterns. Identified three groups of elements are:

1) elements of the underlying technology (pumping);

2) the core elements of the industry;

3) actively evolving elements (Figure 3).

There is a core in the center on the Fig. 3 - the basic technology that is the transfer of pressurized oil by pump units. The basic technical and technological method of the main process was created during the formation of the industry, and the specifics of the industry remained virtually unchanged throughout the life cycle of existence of the system. For more than a century of engineering and technology oil transfer has not changed significantly.

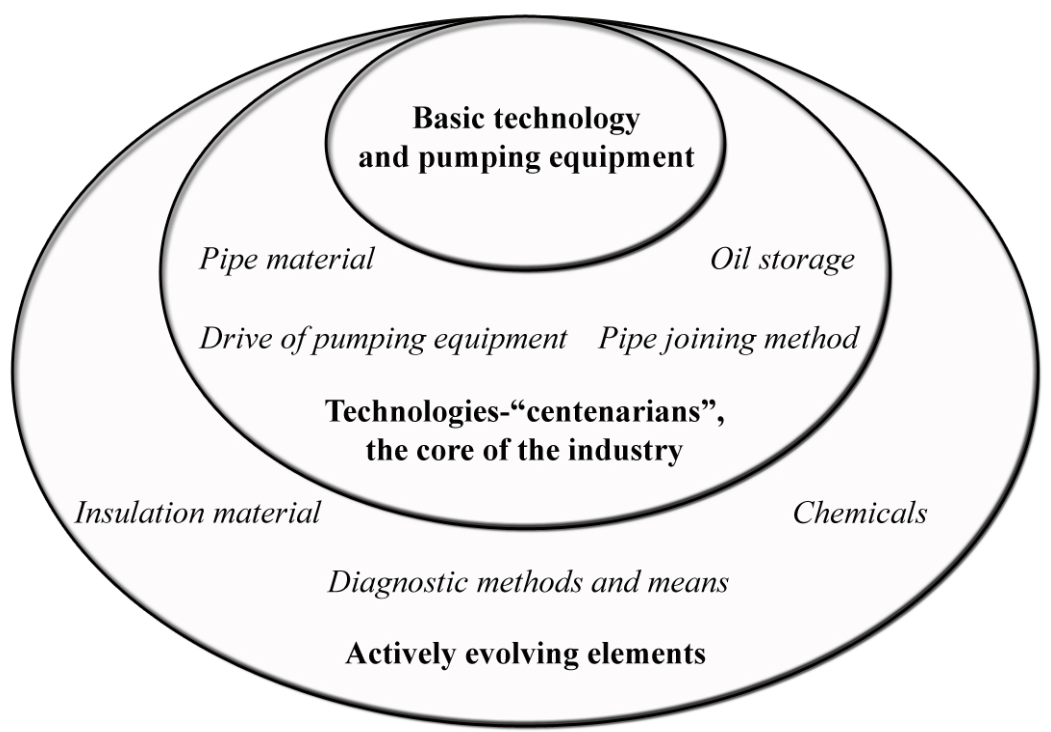

Figure 3: Grouping the pipeline system elements on the innovation speed.

Elements that are conservative from the perspective of the innovative changes are located on the orbit close to the nucleus, and the authors called them technologies-"centenarians". This group includes some elements of pipeline construction (pipe material and technology of pipe connections) and operation processes. These elements are less industry-specific than the basic. Actively evolving elements of the system are the components of processes that are widely used in other industries. These elements belong to diagnostic systems and multifunctional materials. The study revealed that the degree of specificity between the element and the rate of its innovative renewal has an inverse relationship (table 3). 
Table 3: Characteristics of groups of innovation objects in pipeline transport.

\begin{tabular}{|l|c|c|}
\hline Group of elements & $\begin{array}{c}\text { Ratio of } \\
\text { speeds of } \\
\text { innovation }\end{array}$ & $\begin{array}{c}\text { Degree of } \\
\text { specificity of } \\
\text { elements }\end{array}$ \\
\hline 1. Elements of basic technology & 1 & specific \\
\hline 2. Technologies-"centenarians" & 1.2 & partially specific \\
\hline 3. Actively evolving elements & 1.3 & non-specific \\
\hline
\end{tabular}

Revealed patterns can justify the differentiation of innovative renewal speeds of system elements in perspective.

\subsection{Innovative development forecast}

The authors of the study implemented the forecast of development of oil pipeline transportation through 2030 (Table 4). The forecast is based on the characteristics of the structure of the 6th technological way and Foresight estimates of development of the XXI century's priority innovative technologies in EU, U.S. and Japan in the period from 2015 to 2030, given in [10].

Table 4: Innovative development forecast for pipeline system elements (on a scale of technological ways).

\begin{tabular}{|c|c|c|}
\hline Innovation markers & 2010 & 2030 \\
\hline 1. Diagnostic instruments & 5.0 & 5.4 \\
\hline 2. Diagnostic methods & 4.5 & 4.7 \\
\hline 3. $\quad$ Storage tanks materials & 4.0 & 4.0 \\
\hline 4. Control system elements & 4.0 & 4.5 \\
\hline $\begin{array}{l}\text { 5. Construction and equipment } \\
\text { of storage tanks }\end{array}$ & 4.0 & 4.0 \\
\hline 6. Storage technologies & 4.0 & 4.5 \\
\hline 7. Transfer control technology & 4.0 & 4.5 \\
\hline 8. $\quad$ Drive & 3.5 & 3.7 \\
\hline 9. $\quad$ Pump type & 3.0 & 3.0 \\
\hline 10. Pumping technology & 2.0 & 2.0 \\
\hline 11. Construction technologies & 3.0 & 3.5 \\
\hline 12. Construction equipment & 3.5 & 3.7 \\
\hline 13. Pipe joining method & 4.0 & 4.0 \\
\hline 14. Pipe material & 4.0 & 4.0 \\
\hline 15. Insulation material & 5.0 & 5.0 \\
\hline 16. Chemicals & 5.0 & 5.0 \\
\hline
\end{tabular}

Such priority technologies like digital data transfer, more efficient energy consumption technologies, the use of video-, micro-and nanosensors, ultrathin functional coatings, bioactive materials and coatings, structurally "smart" 
materials, nanocomposite materials and some others can change the qualitative appearance of oil transportation. The forecast of prospective development opportunities can be the basis for the formation of innovation policy priorities in Russian oil pipeline transport [11].

Using the authors' proposed innovative approach to the assessment of development based on technological cycles change allows creating an effective monitoring of the development of complex technical systems in the context of processes and their components. In addition, it is possible to accelerate the innovative changes through the use of the factor of the system structure by increasing the proportion of non-specific elements. Evaluating prospective opportunities allows to identify the direction of development correctly and to improve the innovation search efficiency.

\section{References}

[1] Kuzyk B.N., Yakovets Y.V., Integral macroeconomic forecast of innovative technological and the structural dynamics of the economy of Russia until 2030, the Institute for Economic Strategies: Moscow, pp. 349358, 2006.

[2] Glazyev S.Y., Advanced development strategy of Russia in the global crisis, Economics: Moscow, pp. 78-97, 2010.

[3] Karpov V.P., History and development of the West Siberian oil and gas industry (1948-1990), Publishing TGNGU: Tyumen, pp. 75-117, 2005.

[4] Mastobaev B.N., Dmitrieva T.V., Movsumzade E.M., History and production of chemicals for pipeline transport of oil and oil products. Oil Industry, 11, pp. 107-108, 2000.

[5] Khavkin A.Y., Makrorole of oil and gas nanotechnologies. Nanotechnology Environmental Manufacturing, 4 (11), pp. 100-103, 2011.

[6] Khavkin A.Y., Nanotechnology in oil and gas production. Company Sputnik +: Moscow, pp. 50-94, 2008.

[7] Shammazov A.M., Bakhtizin R.N., Mastobaev B.N. and others, History of the pipeline transport of Russia: Lecture notes. Fund to promote research: Ufa, pp. 4-49, 2000.

[8] Shammazov A.M., Bakhtizin R.N., Mastobaev B.N. and others, History of the petroleum industry in Russia: Lecture notes. Fund to promote research: Ufa, pp. 23-52, 2000.

[9] Kablov E.N., Course in the sixth technological way. Engineering Newspaper, February 8, 2010.

[10] Kazantsev A.K., Kiselev B.N., Rubvalter D.A. Rudenskiy O.V., NBICtechnologies: innovative civilization of the twenty-first century, INFRA-M: Moscow, pp. 126-127, 2012.

[11] Zemenkov Y.D., Kurushina V.A., Priorities of the pipeline transport of hydrocarbons in Russia based on an evolutionary approach (Chapter 1). Modern management and innovation, science and technology policy, rev. Sokolov S.M., Milchakova N.N., Publishing House "Science \& Innovation Center": Saint-Louis, pp. 4-28, 2013. 